\title{
THE FEMALE PARAPLEGIC AND MOTHER-CHILD RELATIONS
}

\author{
By R. Turk, M.D., ${ }^{1}$ M. Turk, M.D., ${ }^{1}$ and V. AsseJEv ${ }^{2}$ \\ ${ }^{1}$ Rehabilitation Institute of SR Slovenia, Ljubljana, Yugoslavia. ${ }^{2}$ Clinic for Gynae- \\ cology and Obstetrics, Ljubljana.
}

Summary. This report deals with the problems of the rehabilitation of female paraplegics, including sexual intercourse; conception, delivery, progeny, and motherhood. Successful rehabilitation creates favourable conditions for female paraplegics to bear children.

Team approach to the problems of pregnancy and delivery in paraplegia includes involvement of the gynaecologist, obstetrician and paediatrician. In Slovenia this work is entrusted to the Clinic for Gynaecology and to the Rehabilitation Institute in Ljubljana. While pregnancy in the paraplegic involves risk this does not also apply to the delivery. Complications during pregnancy or delivery do not differ from those occurring in healthy pregnant women or healthy women in labour.

Usually, a paraplegic mother can meet the requirements of nursing, caring for and bringing up her children, thus there is no reason why a properly rehabilitated female paraplegic should not fulfil her life and happiness by becoming a mother.

Key words: Paraplegia; Pregnancy; Delivery; Mother-child relations.

\section{Introduction}

SLOvenIA, a northern Yugoslavian republic of $2025 \mathrm{I} \mathrm{km}^{2}$, has a population of I 800000 . About 40 new severe spinal lesions resulting in paraplegia or tetraplegia states occur annually in this area.

The Ljubljana Rehabilitation Institute is the central institution of this republic, admitting (since I952) patients with severe disability, including paraplegia and tetraplegia. Throughout, we have been improving the rehabilitation programme, relying on our own experience as well as the achievements and views of contemporary developments at home and abroad. Special stress is placed on the multidisciplinary character of team work.

Rehabilitation of paraplegics was until recent times focussed on motor function. But more recently we have realized the importance of other problems, including sexual intercourse, married life, family and progeny. These problems have been tackled hesitatingly, and we have to admit that there was a lack of knowledge of these problems. Modesty, discretion, uneasiness and the like made open dialogue impossible, and prevented more successful intervention in solving many of the numerous ambiguities of the sexual lives of the female paraplegic person.

The present circumstances are different; rehabilitation is better and more successful, the attitude of society has undergone a considerable change, the general living standard has improved, the disabled have begun to take part in sports for the handicapped and they have been taught to drive a car. Considerable efforts have been made to eliminate architectural impediments. Integration and communication have greatly improved. All this 
has created chances for a paraplegic person to consider the possibilities of love, married life and his/her own home, with a wish and a chance of having children.

A woman certainly attains her fulfilment and self-affirmation, joy and happiness if enabled to conceive, give birth to and bring up her own child. By giving birth to a child and through motherhood such a woman undoubtedly fulfils the mission of her life.

Spinal trauma frequently involves young people, and approximately 30 per cent are women. In the last few years there has been a gradual increase in the number of paraplegics who have become married and have borne children. To become mothers some of them even decided to bear an illegitimate child. We are in no doubt that the rehabilitation of paraplegics who become wives and mothers is more complete and successful from several points of view than those who do not give birth.

In Slovenia we have had ten paraplegics who have had children and one who is tetraplegic. Ten gave birth to one child, one has had two children (Table I).

A multidisciplinary team approach is essential; thus, our pregnant paraplegics benefited by the care of a gynaecologist/obstetrician and a paediatrician. Comparing our experiences with those described by Guttmann (I973); Burke and Murray (I975) and Trieschmann (I980), we find no essential difference; however, there is always something special about one's own experience, taking into account local circumstances and the conditions of life, which will always exert an influence upon the choice of specific approaches to rehabilitation.

\section{Conception and sexual life-partnership}

Due to the physiology of sexual intercourse the functions in women are not affected to the same extent as occur in male paraplegics. During sexual intercourse the woman is the more 'passive' partner of the two; she is receiving while the man is giving, so it is logical to conclude that the act does not affect women as much as it does men. A small number of women have permanent amenorrhoea following spinal paraplegia, but menstruation usually recurs in regular cycles some months after the injury, ovulation making normal fertilization possible. The function of the endometrium and uterus remain more or less intact, so that problems of disturbed menstrual cycles, impracticability of sexual intercourse and conception are not frequently encountered in these women. Consequently, from several points of view the partnership between a healthy man and paraplegic woman remains relatively unaffected.

\section{Pregnancy}

The pregnancy of a paraplegic woman should usually be regarded as one involving risks, and a preganant paraplegic should be under proper clinical control. The physician and the obstetrician have to be well informed of the problems specific to the paraplegic state. As there are not very many pregnant paraplegic women, the problems should be dealt with by a single experienced obstetrician in collaboration with a psychiatrist who is in charge of the rehabilitation of the pregnant paraplegic patient. A mutual 


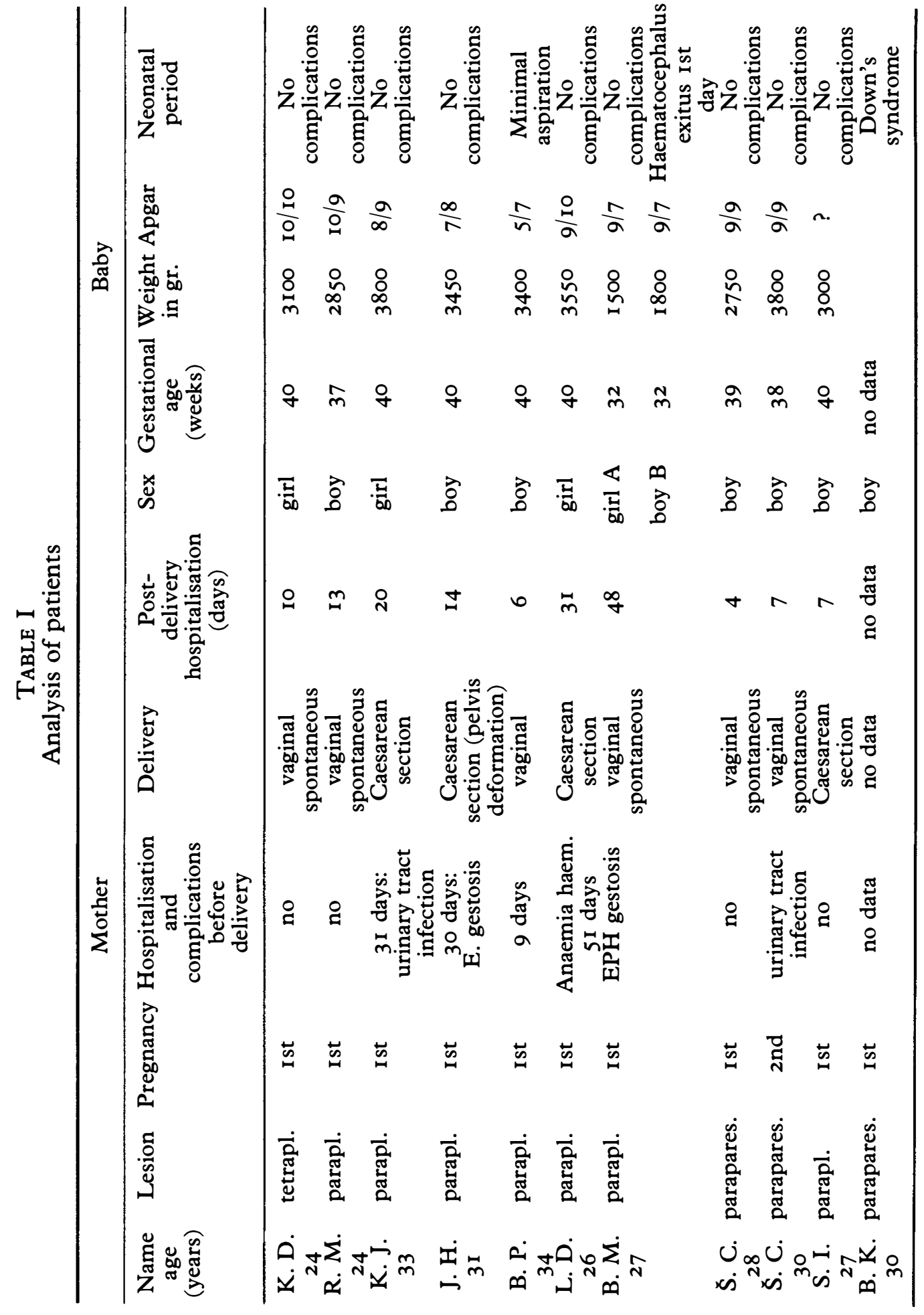


exchange of information is very important. During the pregnancy the paraplegic patient must continue to be active and until late pregnancy her way of life should remain unchanged. It is important that she maintains her proper body weight and remains fit. Thus, she should not give up less arduous sports and recreational activities.

If possible, certain medicines should be avoided during pregnancy, since little is known about the teratogenicity of many pharmaceutical preparations. This applies particularly to the early months of pregnancy when the organogenesis has not yet been completed.

We are concerned that chronic urological problems, specific to paraplegics, might produce a danger and cause disturbance of the urological situation in pregnant paraplegic patients, but our experiences show that we are in fact too pessimistic.

It may be felt that as a result of her sitting position, the uterus in the pregnant paraplegic has a ventral gravitation; and its anteposition does not disturb urodynamics, hence the urine does not stagnate in the upper urinary tract causing pyelonephritis.

Our view is that all pregnant paraplegics should be admitted to the obstetric ward Io to I 4 days before delivery so as to be under proper medical care.

\section{Delivery}

The delivery, as such, carries no risk, but it should be actively directed, closely controlled and monitored. There will be no labour pains so the monitors alone display the power, frequency, contractional efficiency and synchrony of contractions. Regarding other aspects of the delivery, the same rules apply as are necessary for healthy women undergoing childbirth. Four of our paraplegics were delivered by Caesarean section.

Discharge from hospital must be postponed; the baby must be in an optimal condition, and any post-delivery complications threatening the baby and its mother must have been successfully treated.

Even in patients with high spinal lesions lactation is not affected.

\section{Motherhood}

Many laymen and physicians ask if a mother in a wheelchair can satisfy all the requirements of early and later motherhood. It is true that a mother bound to a wheelchair cannot perform all of the duties imposed by motherhood but this depends on the degree of rehabilitation and independence. A poorly rehabilitated, completely dependent and sick paraplegic will probably not plan to have children. However, the paraplegic woman whose rehabilitation has been successful can manage the more difficult tasks of motherhood, especially if assisted by her family.

The nursing, dressing, and bathing of the infant are facilitated also by certain simplified adaptations, rearrangements of furniture and equipment in the apartment. Many people still regard the child of a paraplegic mother as someone excluded from a number of common family enjoyments and genuine contacts. But everything in life is relative, there being no absolute pattern of how one is to attain happiness within one's family or in one's life. Sincere and true love of the child is much more important 
than the intolerable atmosphere occurring in many families embittered by constant quarrels, alcoholism, neglect of children, by immaturity and incompetency of the parents to bring up their children. From our experience, none of the paraplegics have been neglectful where love and upbringing are concerned. This is much more important than having 'healthy and normal parents', who as a result of their human deviations, sadly embitter the childhood and youth of their children.

A co-author of this article is a paediatrician who is in charge of children borne by paraplegic mothers, thus she has a wide knowledge of their progress and their home life. During the visits she pays special attention to such aspects as hygiene, food, education, and the family life of the children. The conclusions drawn from these visits are encouraging and are also deeply touching. There are no signs of negligent nursing, upbringing or negative development. These children are great favourites of their mothers and families, without communication problems in mixing with other children of their own age. They make their mothers happy, and clearly demonstrate the present important progress that has occurred with rehabilitation now being attained by paraplegic women.

\section{RÉSUMÉ}

L' exposé ci-présent s'occupe des problèmes d'une réhabilitation complexe des femmes paraplégiques, y inclu le sexe, la conception, l'accouchement, la progéniture, ainsi que la maternité.

La réhabilitation actuelle crée des conditions favourables pour qu'une paraplégique ait des enfants, ce qui entraine une réduction constante des contre-indications.

Les auteurs exposent le travail en équipe en cas de la grossesse et de l'accouchement d'une paraplégique, l'équipe réhabilitante comportant aussi un gynaecologiste, un accoucheur et un pédiatre. En République socialiste de Slovénie ce travail est confié à la Clinique Gynaecologique et à l'Institut de Réhabilitation (les deux à Ljubljana). La casuistique présentée démontre qu'en principe, la grossesse d'une paraplégique est aléatoire et que l'accouchement ne l'est pas; des complications éventuelles pendant la grossesse ou l'accouchement ne diffèrent pas essentiellement de celles observées en cas des femmes enceintes ou des accouchées non-paraplégiques.

En général, une mère paraplégique est parfaitement à même de soigner, garder et élever ses enfants, par conséquent, sous condition qu'elle se soit proprement réhabilitée, il n'y a aucune raison à ce qu'elle résigne au bonheur de maternité.

\section{ZUSAMMENFASSUNG}

Es wird mitgeteilt über die Probleme der komplexen Rehabilitation der Paraplegikerinnen, zwischen welche gehören gleichfalls Sexualität, Konzeption, Geburt, Nachkommenschaft und die Mutterschaft.

Die heutige erfolgreiche Rehabilitation bietet die Bedingungen, unter welchen die Paraplegikerinnen ihre eigenen Kinder gebären, wodurch der Umfang der Kontraindikationen schmäler wird.

Die Autoren berichten über teammässigen Zutritt bei der Konzeption und Geburt der Kinder seitens der Paraplegikerinnen und dabei sind enthalten Rehabilitations-Team mit dem Ginekologen, Geburtshelfer und dem Pediatär. Auf dem Gebiet der Nordrepublik Jugoslaviens führen diese Arbeit die Ginekologische Klinik in Ljubljana und Institut für Rehabilitation in Ljubljana. Die dargestellte Kasuistik beweist, dass die Konzeption bei Paraplegikerin vorschriftsgemäss risikolös ist, die Geburt aber nicht, während die Komplikationen der Konzeption und der Geburt von den Beispielen der gesunden Mütter, welche sich in Konzeption befinden und die in Geburt stehen, davon nicht ausgeschlossen sind.

Die Mutter Paraplegikerin kann hauptsächlich den Erforderungen der Behandlung, der Obhut und der Erziehung der Kinder vollkommen entsprechen, weshalb aus diesen 
Grüden zu keinen Kontraindikationen kommen kann, dass die Paraplegikerin bei ihrer entsprechenden Rehabilitation nicht ihr Glück und das Leben mit Mutterschaft nicht erreichen könen würde.

\section{REFERENCES}

Burke, D. C. \& Murray, D. D. (1975). Handbook of Spinal Cord Medicine, pp. 6I-65, The Macmillan Press Limited, London.

GutTMAnN, SIR L. (1973). Spinal Cord Injuries-Comprehensive Management and Research, Ist ed., pp. 446-477, Blackwell Scientific Publications, Oxford.

Trieschmann, Roberta B. (1980). Spinal Cord Injuries: Psychological, Social E Vocational Adjustment, pp. I29-146, Pergamon Press Inc., New York. 